\title{
V. SAFETY AND POLLUTION-PREVENTION PROGRAM, DEEP SEA DRILLING PROJECT LEG 50, SITES 415 AND 416
}

\author{
Duane Fritz, Exploration and Production Co., Houston, Texas
}

\section{INTRODUCTION}

The program for safety and pollution-prevention for Leg 50 consisted of two main parts: site selection, and routine shipboard hydrocarbon monitoring. Similar programs have been successfully employed on Legs 47 and 48 , and through a process of trial and experience various procedures were initiated for Leg 50 .

The selection of any site to be drilled by the Deep Sea Drilling Project is the most important part of the safety and pollution-prevention program. A careful site selection, using all available seismic data and geological knowledge to avoid locations where potential hydrocarbon traps, either structural or stratigraphic, may exist, is of the utmost importance. Each proposed site is reviewed by the JOIDES Safety Panel, who may recommend altering the location to another site or even rejecting it completely if the committee feels that a potential hazard exists.

If hydrocarbons may be encountered in significant quantities, a routine shipboard hydrocarbon-monitoring program is established, and all scientists and technicians are familiarized with the procedures.

\section{SITE SELECTION}

Two proposed Leg 50 sites were reviewed by the Safety Panel, proposed site 1 , at $33^{\circ} \mathrm{N}, 11^{\circ} \mathrm{W}$, which was very close to Site 370 , drilled on Leg 41 , and the proposed site 2 , at approximately $31^{\circ} \mathrm{N}, 11^{\circ} 30^{\prime} \mathrm{W}$. Proposed site 2 was given highest priority, because both the water depth and the depth to basement are lesser at this location, and the total sediment thickness is about 3500 meters.

Site 415 is located in the southern part of the Moroccan Basin, at the southwest edge of the Agadir Channel. No positive structure is visible on the available seismic profiles; most of the reflectors are sub-parallel and have low relief. The deepest (yellow) reflector may represent an unconformity, and traps may exist in the truncated sediments. Because data quality below the yellow reflector is poor, and because we did not know what kind of sediments lie below, drilling probably would have been suspended prior to reaching this horizon.

The closest site for comparison is Site 370 of Leg 41, where no ethane and only low amounts of methane were detected. The only other hydrocarbons reported nearby are from fields in the Essouira Basin.

\section{SHIPBOARD ROUTINE HYDROCARBON MONITORING}

The JOIDES Panel on Pollution Prevention and Safety has prepared a manual in connection with the
Deep Sea Drilling Project which is the basis for the safety and pollution-prevention program aboard ship during drilling operations in areas where significant quantities of hydrocarbons may be encountered. The panel also recommended that an experienced petroleum geologist be added to the scientific staff to assist in the hydrocarbon-monitoring program, and required that cores be taken continuously below 1100 meters to total depth to closely monitor hydrocarbons. This depth of 1100 meters was taken from the total depth of Hole 370.

The JOIDES Manual on Pollution Prevention and Safety was circulated to all scientists and technicians before we drilled the first hole of Leg 50. An additional memorandum from the co-chief scientists and shipboard operations manager regarding hydrocarbon safety procedures was also sent to all scientists. The co-chief scientists, operations manager, petroleum geologist, and geochemists discussed the hydrocarbon-monitoring program in detail and outlined methods and responsibilities. During the course of drilling and coring, the cochief scientists, operations manager, and petroleum geologist met daily for briefings on the hydrocarbon monitoring and for general discussions and recommendations concerning the safety program.

Generally, the hydrocarbon-monitoring program consisted of three main elements: (1) visual inspection, (2) gas analysis, and (3) pyrolysis. Other factors, such as shale-density measurements and rate of penetration changes, were taken into account in the overall assessment of the potential danger of encountering significant quantities of hydrocarbons.

\section{Visual Inspection}

As soon as a core was brought to the surface, a small sample was removed from the bottom of the core catcher and checked for fluorescence in the Halliburton ultraviolet-ray box. Samples having any fluorescence were "cut" with chlorothene for determination of hydrocarbons. An additional instrument available for analysis of fluorescence was the Turner Fluorometer, which is useful in detecting levels of fluorescence owing to soluble organic compounds. An increase in the fluorometer reading could indicate enrichment in petroleumtype hydrocarbons where a corresponding increase in organic carbon is absent.

After the core was split, it was examined for possible oil staining and checked in the Halliburton UV box. A checklist of visible characteristics, called the GQF (Gas Quantity Factor), was employed in describing cores for future reference:

0 . No noticeable degassing or detectable hydrocarbons in core sample. 
1. Detectable hydrocarbon gas, but insufficient for reliable analysis. No notable pressure, separating, or bubbling.

2. Sufficient hydrocarbon gas for analysis of core tube samples. Widely scattered bubbling and (or) separation.

3. "Frying" or "chirping" sounds of gas bleeding from cores of indurated sediment. Slight bulging of end caps in storage rack. Minor checking and cracking in softer cores.

4. Pronounced bubbling of gas from core on retrieval. Numerous small separation in soft cores. Strong bulging of end caps.

5. Numerous large separations in soft cores. End caps blown off. Small amounts of soft core extruded from sections on rack.

6. Indications of pressure before opening core barrel. Pronounced expansion of soft core on removal from barrel.

7. Core catcher forcibly blown off.

8. Plug and abandon or set pipe.

This checklist was kept in the core lab, and each core was rated by the criteria above to record estimated gas quantity.

\section{Gas Analysis}

Concurrent with the visual observations, a quick gas analysis was performed on spot cores in Hole 415. Commencing with Core 415A-5, all cores were analyzed for hydrocarbon gas. One sample was taken as soon as the plastic liner containing the core was capped. Likely pockets of potential gas were sampled, or the plastic tube was tilted so that all the water rushed toward the bottom and helped trap the gas. In other cases, a sample was analyzed after the core was sealed for one or more hours. This delay presumably allowed more of the heavier gases to escape from the matrix, giving a more meaningful ratio between methane and heavier gases.

The gas sample was extracted into a vacuum vial and immediately taken to the geochemistry lab for analysis. First, a 50- $\mu$ l sample was taken from the vial, and the gas was analyzed by the Carle Gas Chromatograph to give percentages of $\mathrm{CH}$ and $\mathrm{CO}_{2}$ in approximately one to one and a half minutes. This rapid reading of the amount of methane in the gas could be related to previous samples taken to indicate any rapid and large increase in gas concentrations.

A second $1.0-\mathrm{m} \ell$ sample was extracted for analysis by the Hewlett-Packard 5710A Gas Chromatograph, which was installed with a Columbia Scientific Instruments Model CSI 38 Digital Integrator. The Hewlett-Packard gave readings in parts per million for ethane, propane, butane, and pentane $\left(\mathrm{C}_{2}-\mathrm{C}_{5}\right)$. This analysis, which involves alternating cold and hot baths, takes approximately 15 minutes.

From the results of both chromatographs, the ratio $C_{1} / C_{2}+$ was established and plotted graphically against depth. This ratio is an indicator of the proximity of a potentially dangerous interval of hydrocarbon entrapment. Excessively low values of this ratio would be reason to abandon a site. One would expect this ratio to gradually decrease with depth, even where no other evidence for hydrocarbon accumulation exists; therefore, this ratio is not by itself evidence of proximity to entrapped hydrocarbons.

\section{Pyrolysis}

A sample from each core below Core $415 \mathrm{~A}-4$ was analyzed to determine the type of organic material present and the ratio of generated hydrocarbons to total hydrocarbons. The combination of data can be used to determine the hydrocarbon-generating potential of sediments and to establish whether the sediment contains migrated hydrocarbons. Estimates of the maturation of the sediments-depth and temperature of expected hydrocarbon generation-can be made. The device used for pyrolysis determination was a prototype analyzer provided by IFP/FINA. The analyzer quickly and accurately assesses four properties: (1) $S_{l}$, the quantity of hydrocarbons present in the rock; (2) $S_{2}$, the hydrocarbon compounds produced by cracking of the kerogen up to $550^{\circ} \mathrm{C}$; (3) $S_{3}$, the $\mathrm{CO}_{2}$ produced by the pyrolyzed organic matter; and (4) the temperature, $T$, corresponding to the maximum of hydrocarbon compounds produced during the pyrolysis of kerogen. From these properties one can: (a) identify the type of organic matter, (b) interpret the petroleum potential of the organic matter, (c) interpret the maturation of the organic matter, (d) interpret the meaning of oil shows.

A continual record of these results was maintained and used in conjunction with the gas analysis and visual observations to evaluate sampled sediments and to predict potentially hazardous hydrocarbon accumulation. A sample for pyrolysis was routinely taken from the core catcher of each core and was analyzed immediately. This "quick" analysis took only about 15 minutes and gave a rapid approximation, for safety purposes, of generated hydrocarbons. The sample was completely dried and references made for a complete pyrolysis analysis; this analysis took approximately one and a half hours. Both analyses were taken into account in assessing the possibility of encountering large amounts of hydrocarbons. The "quick analysis" was used to evaluate the results of the chromatograph analysis in deciding whether to continue coring. Coring operations would have been halted immediately if at any time an excessively low $\mathrm{C}_{1} / \mathrm{C}_{2}+$ ratio had been found in conjunction with indications, from pyrolysis results, of large quantities of generated hydrocarbons. All available data on geochemical results and knowledge of the anticipated geologic section would have to be analyzed before reaching a decision to either continue coring or plug and abandon.

\section{SITE 415}

\section{Cenozoic}

\section{Hole 415}

Five cores were taken in Hole 415, the pilot hole. No hydrocarbon fluorescence or "cut" was detected in any of these cores. The sampling depths ranged from sea 
bottom, 2817 meters, to 3100 meters ( $283 \mathrm{~m}$ below sea floor). The sediments ranged from Pleistocene to lower Miocene. Gas samples were not routinely taken. Data from samples taken in Cores $415-3$ and 415-5 are presented in Table 1.

\section{Hole 415A}

Each core in Hole 415A was monitored for hydrocarbons, utilizing all available methods. Cores were taken from 3199 meters to 3236 meters (349-519 m below sea floor). The section comprised Paleocene to Upper Cretaceous sediments. The Upper Cretaceous was identified in the bottom of the core-catcher sample of Core 415A-7 (3226.5-3336 m). Cores 415A-1 through $415 \mathrm{~A}-4$ were not analyzed, because there was no recovery or very little recovery. Pyrolysis data given in Table 2 were derived only from the "quick" determinations made aboard ship.

The high $\mathrm{C}_{1} / \mathrm{C}_{2}+$ ratios for all measured Cenozoic sediments, and the pyrolysis measurement on Core $415 \mathrm{~A}-5$, indicated poor source rocks for hydrocarbon generation and no evidence of proximity to any significant hydrocarbon accumulations.

\section{Mesozoic}

\section{Hole 415A}

The Cretaceous was identified in the core-catcher sample of Core 415A-7, 3326.5 to 3336 meters (509.5$519 \mathrm{~m}$ below sea floor). Seven cores were taken within the Cretaceous section from the base of Core 415A-7 to a total depth of 3896.5 meters $(1079.5 \mathrm{~m}$ below sea floor). Drilling penetrated to the upper Albian. The pyrolysis data are presented in Table 3.

The "quick" gas analysis indicated a major decrease in the ratio $C_{1} / C_{2}+$ between Cores $415 \mathrm{~A}-10$ and $415 \mathrm{~A}-11$. Core $415 \mathrm{~A}-10$ had a $\mathrm{C}_{1} / \mathrm{C}_{2}+$ ratio of 1135 , and Core $415 \mathrm{~A}-11$ had a ratio of 567 . The ratio re- mained between 400 and $500^{+}$through the final core, $415 \mathrm{~A}-14$. While this rapid narrowing of the ratio $\mathrm{C}_{1} / \mathrm{C}_{2}+$ could have been cause for alarm, the quantities of $\mathrm{C}_{2}-\mathrm{C}_{5}$ were relatively low, and the ratio $\mathrm{C}_{1} / \mathrm{C}_{2}+$ was not at a critical level. The pyrolysis data derived from samples of Cores $415 \mathrm{~A}-13$ and $415 \mathrm{~A}-14$ indicated that the sediments contain little generated hydrocarbons and that the kerogens are type $2-3$, which we considered poor source rocks. The degree of maturation was low; Core 415A-14 was in an immature stage, but approaching maturity.

Drilling at Hole 415A was terminated abruptly, owing to extremely bad hole conditions at a depth of 3896.5 meters below sea surface. Preparations had been underway for continuous coring as a safety measure. The increase in $\mathrm{CH}_{4}$ percentage and the narrowing in values of $C_{1} / C_{2}+$ caused us to very closely and carefully scrutinize each core by all three methods of observation, but we encountered no indications that would have led us to abandon the hole for safety reasons.

The combination of visual observation, gas analyses, and pyrolysis seems to be the best method yet devised of ensuring safety while drilling.

\section{SITE 416}

\section{Cenozoic}

Two cores were taken in the pilot hole, Hole 416, with poor recovery. No gas samples were taken.

Five cores were taken in Hole 416A in the Cenozoic from 4349 to 4967.5 meters (146-763 m below sea floor). The information derived from these cores is given in Table 4.

Only minor amounts of methane and ethane were found in the Cenozoic sediments. The pyrolysis data indicate that the sediments are generally immature, with little or no generated hydrocarbons and only small potential for hydrocarbons.

TABLE 1

Gas Analyses for Cenozoic Sediments of Hole 415

\begin{tabular}{|c|c|c|c|c|c|c|}
\hline Core & $\begin{array}{c}\text { Interval } \\
\text { (m below sea surface) }\end{array}$ & Series & Lithology & $\begin{array}{l}\mathrm{CH}_{4} \\
(\%)\end{array}$ & $\begin{array}{l}\mathrm{C}_{2}-\mathrm{C}_{5} \\
(\mathrm{ppm})\end{array}$ & $\mathrm{C}_{1} / \mathrm{C}_{2}$ \\
\hline $415-3$ & $2954.5-2964$ & M. Miocene & Nannofossil marl & 0.032 & n.d. & n.d. \\
\hline $415-5$ & $3090.5-3100$ & L. Miocene & $\begin{array}{l}\text { Nannofossil ooze and } \\
\text { marl with siliceous } \\
\text { debris }\end{array}$ & 0.32 & $\mathrm{C}_{2}=2.9$ & 1100 \\
\hline
\end{tabular}

TABLE 2

Gas Analyses and Pyrolysis Data for Cenozoic Sediments of Hole $415 \mathrm{~A}^{\mathrm{a}}$

\begin{tabular}{|c|c|c|c|c|c|c|}
\hline Core & $\begin{array}{c}\text { Interval } \\
\text { (m below sea surface) }\end{array}$ & Fluor. & GQF & $\begin{array}{l}\text { Methane } \\
(\%)\end{array}$ & $\mathrm{C}_{1} / \mathrm{C}_{2}$ & Pyrolysis Data \\
\hline $415 \mathrm{~A}-5$ & $\begin{array}{ll}3260 & -3269.5\end{array}$ & None & 3 & $\begin{array}{r}7.45 \\
27.33\end{array}$ & $\begin{array}{r}15,206 \\
3,284\end{array}$ & $\begin{array}{l}0.8 \% \text { pyrolizable carbon } \\
\text { kerogen type } 3\end{array}$ \\
\hline $415 \mathrm{~A}-6$ & $3269.5-3326.5$ & None & 3 & 20.2 & 3,686 & - \\
\hline $415 \mathrm{~A}-7$ & $3326.5-3336.0$ & None & 1 & 19.2 & - & $\begin{array}{l}0.2 \% \text { pyrolizable carbon } \\
\text { kerogen type } 2 \text { ? }\end{array}$ \\
\hline
\end{tabular}

\footnotetext{
ayrolysis data by "quick" method only.
} 
TABLE 3

Gas Analyses and Pyrolysis Data for Mesozoic Sediments of Hole 415A

\begin{tabular}{|c|c|c|c|c|c|c|}
\hline Core & $\begin{array}{c}\text { Interval } \\
\text { ( } \mathrm{m} \text { below sea surface) }\end{array}$ & Fluor. & GQF & $\begin{array}{l}\text { Methane } \\
(\%)\end{array}$ & $\mathrm{C}_{1} / \mathrm{C}_{2}$ & Pyrolysis Data \\
\hline $415 \mathrm{~A}-8$ & $\begin{array}{ll}3336 & -3402.3\end{array}$ & 0 & $3-4$ & 16.7 & 1156 & n.d. \\
\hline $415 A-9$ & $3459.3-3469$ & 0 & 4 & $\begin{array}{l}68.5 \\
29.8^{\mathrm{a}}\end{array}$ & $\begin{array}{c}3166 \\
953^{a}\end{array}$ & $\begin{array}{l}\text { n.d. } \\
\text { n.d. }\end{array}$ \\
\hline $415 \mathrm{~A}-10$ & $3526-3535.5$ & 0 & 2 & 57.5 & 1135 & n.d. \\
\hline $415 \mathrm{~A}-11$ & $3611.5-3621$ & 0 & 2 & 17.4 & 567 & n.d. \\
\hline $415 \mathrm{~A}-12$ & $\begin{array}{ll}3697 & -3706.5\end{array}$ & 0 & 5 & 39.8 & 438 & n.d. \\
\hline $415 \mathrm{~A}-13$ & $3773-3782.5$ & 0 & 4 & $\begin{array}{l}42.6 \\
30.4^{\mathrm{a}}\end{array}$ & $\begin{array}{l}588 \\
369^{\mathrm{a}}\end{array}$ & $\begin{array}{l}\text { Very little generated hydrocarbons, } \\
\text { little potential } \\
\text { kerogen type } 3 \text {, poor source }\end{array}$ \\
\hline $415 \mathrm{~A}-14$ & $\begin{array}{ll}3849 & -3858.0\end{array}$ & 0 & 3 & $\begin{array}{l}62.4 \\
59.8^{\mathrm{a}}\end{array}$ & $\begin{array}{l}514 \\
402^{\mathrm{a}}\end{array}$ & $\begin{array}{l}\text { Very little generated hydrocarbons, } \\
\text { very small potential, } \\
\text { kerogen type } 2-3 \text {, poor source }\end{array}$ \\
\hline
\end{tabular}

${ }^{\mathrm{a}}$ Gas sample measured after waiting one or more hours to sample from plastic liner.

TABLE 4

Gas Analyses and Pyrolysis Data for Cenozoic Sediments of Hole 416A

\begin{tabular}{|c|c|c|c|c|c|c|}
\hline Core & $\begin{array}{c}\text { Interval } \\
\text { (m below sea surface) }\end{array}$ & Fluor. & GQF & $\begin{array}{l}\mathrm{CH}_{4} \\
(\%)\end{array}$ & $\mathrm{C}_{1} / \mathrm{C}_{2}+$ & Pyrolysis Data \\
\hline $416 \mathrm{~A}-1$ & $4349-4358.5$ & None & 0 & 0.0005 & n.d. & $\begin{array}{l}\text { No generated hydrocarbons; } \\
\text { very immature; } 0.7 \mathrm{mg} / \mathrm{g} \\
\text { potential hydrocarbons }\end{array}$ \\
\hline $416 \mathrm{~A}-2$ & $4501-4510.5$ & None & 0 & 0.0005 & n.d. & Same \\
\hline $416 \mathrm{~A}-3$ & $4653-4662.5$ & None & 1 & $\begin{array}{c}0.8 \\
11.8^{\mathrm{a}}\end{array}$ & $\begin{array}{l}\text { n.d. } \\
6330^{\mathrm{a}}\end{array}$ & Same \\
\hline $\begin{array}{l}416 \mathrm{~A}-4 \\
416 \mathrm{~A}-5\end{array}$ & $\begin{array}{l}4805-4814.5 \\
4957-4967.5\end{array}$ & $\begin{array}{l}\text { None } \\
\text { None }\end{array}$ & $\underset{3}{\text { n.d. }}$ & $\begin{array}{l}\text { n.d. } \\
10.7^{\mathrm{a}}\end{array}$ & $\begin{array}{l}\text { n.d. } \\
3100^{\mathrm{a}}\end{array}$ & $\begin{array}{l}\text { Very slight generated hydro- } \\
\text { carbons; } 3.6 \mathrm{mg} / \mathrm{g} \text { potential } \\
\text { hydrocarbons; immature } \\
\text { sediments }\end{array}$ \\
\hline
\end{tabular}

${ }^{\text {a }}$ Sample taken after cores remained one or more hours on the core rack.

\section{Mesozoic}

Forty-six cores were taken from Cretaceous (Albian through Berriasian) sediments of Core 416A-5 through Core 416A-51. A summary of the data is given in Table 5. In general, the Cretaceous sediments sampled from Hole $416 \mathrm{~A}$ were characterized by very small amounts of gas. From Core 416A-7 through Core 416A-51 methane amounted to less than 1 per cent. Below Core 416A-31, samples taken immediately after the cores were brought on deck had methane concentrations too small to measure. Only after the core had remained two or more hours on the rack was gas obtained in measurable quantities. The ratio $C_{1} / C_{2}+$ and the ratios of $C_{3}, C_{4}$, and $C_{5}$ are more typical of petroleum gases, but the extremely low volume of gas negated any cause for alarm.
Pyrolysis data through Core 416A-51 indicated no generated hydrocarbons, only minor potential for hydrocarbons, and probably type- 3 kerogen. From approximately 1200 meters, the sediments are mature but have not reached maximum maturity.

Five cores were taken from sediments (416A-53 to 416A-57) from 5787 meters to 5827 meters below sea surface. As in the Cretaceous sediments, the methane quantity was too low to measure when cores were sampled immediately. Even following a delay of more than two hours only very small amounts of gas were recorded.

Pyrolysis data from Cores 416A-52 (Berriasian) and 416A-57 indicate very little generated hydrocarbons, very little potential for hydrocarbons, and only a beginning stage of maturation. 
TABLE 5

Gas Analyses and Pyrolysis Data for Mesozoic Sediments of Hole 416A

\begin{tabular}{|c|c|c|c|c|c|c|}
\hline Core & $\begin{array}{c}\text { Interval } \\
\text { ( } \mathrm{m} \text { below sea surface) }\end{array}$ & Fluor. & GQF & $\begin{array}{l}\mathrm{CH}_{4} \\
(\%)\end{array}$ & $\mathrm{C}_{1} / \mathrm{C}_{2}+$ & Pyrolysis Data \\
\hline $416 A-6$ & $5094-5099.5$ & None & 3 & $8.7^{\mathrm{a}}$ & $5118^{a}$ & $\begin{array}{l}\text { Very little generated hydrocarbons; } \\
\text { low potential hydrocarbons, } \\
\text { kerogen type } 3 \text {; immature }\end{array}$ \\
\hline $416 \mathrm{~A}-7$ & $5194.5-5296$ & None & 1 & 0.11 & n.d. & Same \\
\hline 416A-8 & $\begin{array}{lll}5293 & -5321.5\end{array}$ & None & 0 & n.d. & n.d. & Same \\
\hline 416A-9 & $5379-5388$ & None & 0 & 0.0005 & n.d. & Same \\
\hline $416 \mathrm{~A}-10$ & $5388.4-5397.8$ & None & 1 & 0.06 & n.d. & Same \\
\hline $416 \mathrm{~A}-11$ & $5397.8-5407.3$ & None & 1 & $\begin{array}{l}0.06^{\mathrm{a}} \\
0.04\end{array}$ & 120 & Same \\
\hline $416 \mathrm{~A}-12$ & $5407.3-5416.8$ & None & 1 & $\begin{array}{l}0.17^{\mathrm{a}} \\
0.09\end{array}$ & $122^{\mathrm{a}}$ & Same \\
\hline $416 \mathrm{~A}-13$ & $5416.8-5425.4$ & None & 1 & $0.08^{\mathrm{a}}$ & $200^{\mathrm{a}}$ & Same \\
\hline $416 \mathrm{~A}-14$ & $5426.4-5435.9$ & None & 1 & $0.08^{\mathrm{a}}$ & $150^{\mathrm{a}}$ & Same \\
\hline $416 \mathrm{~A}-15$ & $5435.9-5445.5$ & None & 1 & $\begin{array}{l}0.75^{\mathrm{a}} \\
0.02\end{array}$ & $250^{\mathrm{a}}$ & Same \\
\hline $416 A-16$ & $5445.5-5455$ & None & 1 & $\begin{array}{l}0.19 \\
0.008\end{array}$ & $345^{a}$ & Not measured very little gen \\
\hline $416 \mathrm{~A}-17$ & 5455.5464 .5 & None & 1 & $\begin{array}{l}0.09^{\mathrm{a}} \\
0.03\end{array}$ & $160^{\mathrm{a}}$ & $\begin{array}{l}\text { Not measured; very little gen. } \\
\text { hydrocarbons, small poten. } \\
\text { hydrocarbons, kerogen type } 3 \text {, } \\
\text { maturity increasing slightly } \\
\text { but still immature }\end{array}$ \\
\hline $416 \mathrm{~A}-18$ & 5464.5 .5474 & None & 1 & $\begin{array}{l}0.09^{\mathrm{a}} \\
0.01\end{array}$ & $330^{\mathrm{a}}$ & Same \\
\hline $416 \mathrm{~A}-19$ & $5474 \quad-5480.5$ & None & 1 & $\begin{array}{l}0.09^{a} \\
0.02-0.06\end{array}$ & $236^{\mathrm{a}}$ & Same \\
\hline $416 \mathrm{~A}-20$ & $5480.5-5490$ & None & 1 & $0.15^{\mathrm{a}}$ & $263^{a}$ & Same \\
\hline $416 A-21$ & $5493 \quad-5502.5$ & None & 1 & $\begin{array}{l}0.07^{\mathrm{a}} \\
0.02\end{array}$ & $86^{\mathrm{a}}$ & Same \\
\hline $416 \mathrm{~A}-22$ & $5502.5-5512.1$ & None & 1 & $0.23^{\mathrm{a}}$ & $150^{\mathrm{a}}$ & Same \\
\hline $\begin{array}{l}416 \mathrm{~A}-23 \\
416 \mathrm{~A}-24\end{array}$ & $\begin{array}{l}5512.1-5521.6 \\
5521.6-5530.7\end{array}$ & $\begin{array}{l}\text { None } \\
\text { None }\end{array}$ & $\begin{array}{c}0-1 \\
1\end{array}$ & $\begin{array}{l}0.15^{\mathrm{a}} \\
0.11^{\mathrm{a}}\end{array}$ & $\begin{array}{l}149^{\mathrm{a}} \\
122^{\mathrm{a}}\end{array}$ & $\begin{array}{l}\text { Same } \\
\text { Same }\end{array}$ \\
\hline $416 \mathrm{~A}-25$ & $5530.7-5539.2$ & None & 1 & $0.08^{\mathrm{a}}$ & $124 \mathrm{a}$ & Same \\
\hline $416 A-26$ & $5540.2-5549.7$ & None & 1 & $\begin{array}{l}0.09 \mathrm{a} \\
0.008\end{array}$ & $157^{a}$ & Same \\
\hline $416 A-27$ & $5549.7-5594.4$ & None & 1 & 0.008 & n.d. & Same \\
\hline $416 A-28$ & $5594.4-5568.9$ & None & 1 & $0.04^{\mathrm{a}}$ & $147^{\mathrm{a}}$ & Same \\
\hline $416 \mathrm{~A}-29$ & $5568.9-5578.2$ & None & 1 & $\begin{array}{l}0.04^{\mathrm{a}} \\
0.004 \\
0.04 \mathrm{a}\end{array}$ & $59^{\mathrm{a}}$ & Same \\
\hline $416 \mathrm{~A}-30$ & $5578.2-4487.6$ & None & 1 & $\begin{array}{l}0.04^{\mathrm{a}} \\
0.008\end{array}$ & $69^{\mathrm{a}}$ & Same \\
\hline $416 \mathrm{~A}-31$ & $5587.6-5597.1$ & None & 0 & $0.02^{\mathrm{a}}$ & $130^{\mathrm{a}}$ & Same \\
\hline $416 \mathrm{~A}-32$ & $5597.1-5606.6$ & None & 0 & $0.05^{\mathrm{a}}$ & $81^{\mathrm{a}}$ & Same \\
\hline $416 \mathrm{~A}-33$ & $5606.6-5609.8$ & None & 0 & 0.0005 & n.d. & Same \\
\hline $416 A-34$ & $5609.8-5619.4$ & None & 0 & $0.12^{\mathrm{a}}$ & $120^{\mathrm{a}}$ & Same \\
\hline $416 \mathrm{~A}-35$ & $4519.4-4528.4$ & None & 0 & $0.02^{\mathrm{a}}$ & n.d. & Same \\
\hline $416 \mathrm{~A}-36$ & $5628.4-5638$ & None & 0 & $0.01^{\mathrm{a}}$ & $160^{\mathrm{a}}$ & Same \\
\hline 416A-37 & $5638-5648$ & None & 0 & 0.0005 & n.d. & $\begin{array}{l}\text { n.d. } \\
\text { Too small to measure }\end{array}$ \\
\hline $416 A-38$ & $5648-5653$ & None & 0 & 0.0005 & n.d. & Too small to measure \\
\hline $416 \mathrm{~A}-39$ & $5653.7-5657.5$ & None & 0 & n.d. & n.d. & n.d. \\
\hline $416 \mathrm{~A}-40$ & $5657.5-5666.9$ & None & 0 & $\begin{array}{l}0.0005 \\
0.02^{\mathrm{a}}\end{array}$ & $100^{\mathrm{a}}$ & $\begin{array}{l}\text { No generated hydrocarbon, very } \\
\text { small potential, hydrocarbon, } \\
\text { probably kerogen type } 3\end{array}$ \\
\hline $416 A-41$ & $5666.9-5676.3$ & None & 0 & 0.0005 & n.d. & Same \\
\hline $416 \mathrm{~A}-42$ & $5676.3-5685.4$ & None & 0 & 0.0005 & n.d. & Same \\
\hline $416 \mathrm{~A}-43$ & $5685.4-5694.4$ & None & 1 & 0.003 & n.d. & Same \\
\hline $416 \mathrm{~A}-44$ & $5694.9-5704.2$ & None & 0 & n.d. & n.d. & $\begin{array}{l}\text { No gen. hydrocarbons very } \\
\text { small potential hydrocarbon, } \\
\text { probably kerogen type } 3\end{array}$ \\
\hline $416 \mathrm{~A}-45$ & $5704.2-5713.6$ & None & 0 & n.d. & n.d. & Same \\
\hline $416 \mathrm{~A}-46$ & $5713.6-5723$ & None & 0 & n.d. & n.d. & Same \\
\hline $416 A-47$ & $\begin{array}{lll}5723 & -5732.5\end{array}$ & None & 0 & n.d. & n.d. & $\begin{array}{l}\text { No gen. hydrocarbons very small } \\
\text { potential hydrocarbon, } \\
\text { probably kerogen type } 3\end{array}$ \\
\hline $416 \mathrm{~A}-48$ & $5732.5-5742.1$ & None & 0 & $0.016^{\mathrm{a}}$ & $235^{\mathrm{a}}$ & Same \\
\hline $416 A-49$ & $5742.1-5751.6$ & None & 0 & $0.03^{a}$ & $252^{\mathrm{a}}$ & Same \\
\hline $416 \mathrm{~A}-50$ & $5751.6-5761$ & None & 0 & 0.03 & 195 & Same \\
\hline $416 A-51$ & $5761-5770.4$ & None & 0 & 0.05 & 248 & Same \\
\hline $416 \mathrm{~A}-52$ & $5770.4-5779.8$ & None & $0-1$ & $0.05^{\mathrm{a}}$ & $240^{\mathrm{a}}$ & $\begin{array}{l}\text { Very poor potential, very little } \\
\text { generated }\end{array}$ \\
\hline $416 A-53$ & $5779.8-5789.2$ & None & 1 & $0.006^{\mathrm{a}}$ & n.d. & n.d. \\
\hline $416 A-54$ & $5789.2-5798.6$ & None & n.d. & n.d. & n.d. & n.d. \\
\hline $416 \mathrm{~A}-55$ & $5798.6-5808$ & None & n.d. & n.d. & n.d. & n.d. \\
\hline $416 \mathrm{~A}-56$ & $\begin{array}{ll}5808 & -5817.5 \\
5817 & 5-5827\end{array}$ & None & n.d. & n.d. & n.d. & $\begin{array}{l}\text { n.d. } \\
\text { Very noor notential verv litule }\end{array}$ \\
\hline $416 A-57$ & $5817.5-5827$ & None & n.d. & n.d. & n.d. & $\begin{array}{l}\text { Very poor potential, very little } \\
\text { generated hydrocarbon }\end{array}$ \\
\hline
\end{tabular}

${ }^{a}$ Sample taken after core remained one or more hours on the core rack. 